\title{
The Dynamic Movement of Plutonium in an Underground Nuclear Test with Implications for the Contamination of Groundwater
}

D.K. Smith, R.W. Williams

This article was submitted to

Sixth International Conference on Methods and Applications of Radioanalytical Chemistry

Kona, HI, April 7-11, 2003

U.S. Department of Energy

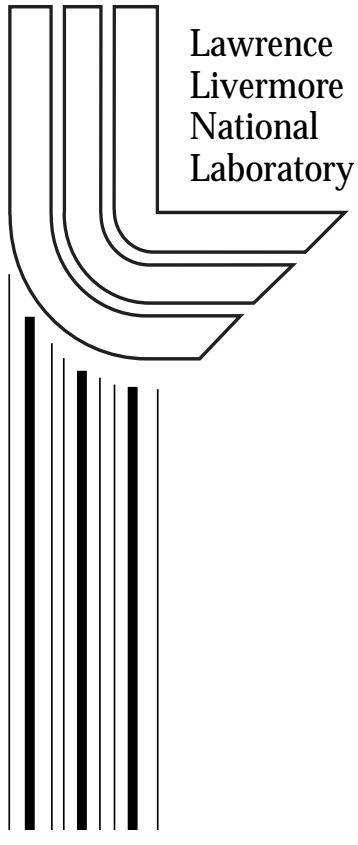

\section{March 25, 2003}




\section{DISCLAIMER}

This document was prepared as an account of work sponsored by an agency of the United States Government. Neither the United States Government nor the University of California nor any of their employees, makes any warranty, express or implied, or assumes any legal liability or responsibility for the accuracy, completeness, or usefulness of any information, apparatus, product, or process disclosed, or represents that its use would not infringe privately owned rights. Reference herein to any specific commercial product, process, or service by trade name, trademark, manufacturer, or otherwise, does not necessarily constitute or imply its endorsement, recommendation, or favoring by the United States Government or the University of California. The views and opinions of authors expressed herein do not necessarily state or reflect those of the United States Government or the University of California, and shall not be used for advertising or product endorsement purposes.

This is a preprint of a paper intended for publication in a journal or proceedings. Since changes may be made before publication, this preprint is made available with the understanding that it will not be cited or reproduced without the permission of the author.

This report has been reproduced directly from the best available copy.

Available electronically at http://www.doc.gov/bridge

Available for a processing fee to U.S. Department of Energy

And its contractors in paper from

U.S. Department of Energy

Office of Scientific and Technical Information

P.O. Box 62

Oak Ridge, TN 37831-0062

Telephone: (865) 576-8401

Facsimile: (865) 576-5728

E-mail: reports@adonis.osti.gov

Available for the sale to the public from

U.S. Department of Commerce

National Technical Information Service

5285 Port Royal Road

Springfield, VA 22161

Telephone: (800) 553-6847

Facsimile: (703) 605-6900

E-mail: orders@ntis.fedworld.gov

Online ordering: http://www.ntis.gov/ordering.htm

OR

Lawrence Livermore National Laboratory

Technical Information Department's Digital Library

http://www.llnl.gov/tid/Library.html 


\title{
The dynamic movement of plutonium in an underground nuclear test with implications for the contamination of groundwater
}

\author{
D.K. Smith, ${ }^{1}$, R.W. Williams ${ }^{1}$ \\ ${ }^{1}$ Chemistry and Materials Science Directorate, Lawrence Livermore National Laboratory, \\ Livermore, CA 94550 USA
}

\begin{abstract}
The recent discovery of the migration of plutonium in groundwater away from underground nuclear tests at the Nevada Test Site has spawned considerable interest in the mechanisms by which plutonium may be released to the environment by a nuclear test. A suite of solid debris samples was collected during drilling through an expended test cavity and the overlying collapse chimney. Uranium and plutonium were analyzed for isotope ratios and concentration using high precision magnetic sector inductively coupled mass spectrometry. The data unequivocally shows that plutonium may be
\end{abstract} dispersed throughout the cavity and chimney environment at the time of the detonation. The ${ }^{239} \mathrm{Pu} /{ }^{240} \mathrm{Pu}$ ratios are also fractionated relative to initial plutonium isotope ratio for the test device. Fractionation is the result of the volatilization of uranium and production of ${ }^{239} \mathrm{Pu}$ by the reaction ${ }^{238} \mathrm{U}(\mathrm{n}, \square$. We conclude that for the test under consideration plutonium was deposited outside of the confines of the cavity by dynamic processes in early-time and it is this plutonium that is most likely first transferred to the groundwater regime. 


\section{INTRODUCTION}

The migration of radionuclides associated with underground nuclear tests involves transport processes that occur at or near the time of the detonation as well as hydrologic processes that occur over longer time scales. While much effort has been

devoted to study and assessments of transport of radionuclides in groundwater ${ }^{1-4}$ there has been less effort focused on studying early-time processes affecting the dispersal radionuclides within and adjacent to an underground nuclear explosion.

Many questions hinge on the results of a study of this kind. Numerical models of the saturated release and subsequent groundwater transport of radionuclides from underground nuclear explosions are extremely sensitive to where radionuclides are initially distributed following the explosion ${ }^{4}$. In particular radionuclides that are not volumetrically incorporated in the melt glass produced by fusion of host rock during the detonation are likely transferred to groundwater by surface reactions involving ion exchange with groundwater. At the Nevada Test Site "prompt injection" has also been documented at many sites of underground nuclear explosions since radionuclide investigations began in the mid-1970's ${ }^{5-6}$. There is the perceived concern that radionuclides may be introduced directly into groundwater at the time of explosion.

The implications of such transport are significant. A lingering and unresolved question associated with the 1997 discovery of colloidal facilitated transport of plutonium beneath Pahute Mesa is the role of explosion phenomenology in the observed migration of radionuclides ${ }^{3}$. The distribution of plutonium within the underground environment of a nuclear test is not known, nor is the extent to which plutonium may have been 
transported within or outside of the cavity at the time of the detonation. If migration can be attributed in part to the explosion, groundwater transport velocities will, by necessity, be slower.

During a nuclear explosion, the energy release is significant and leads to instantaneous mechanical disruption and shock melting of the rock adjacent to the explosion. The extreme temperatures (1M degrees) and pressure (1Mbar) creates a shock wave that propagates outward radially away from ground zero. Within microseconds the energy melts the rock and within milliseconds it crushes and cracks the rock that was not fused. During this process, a cavity is created that expands outwards until the internal pressure and momentum of the shock wave are equalized by the by the confining strength of the surrounding rock. More than 700 metric tons of rock is fused per kiloton of nuclear yield ${ }^{7-8}$. The melted rock coalesces at the bottom of the standing cavity until, within minutes to hours, the cavity pressure is relieved and the cavity collapses. Rubble invades the still molten glass and the former standing cavity. If the material strength of the rock is insufficient, collapse can proceed to the groundsurface and form a crater ${ }^{8}$.

A study of the radiological distribution of melt glass and explosive rubble from the PILEDRIVER test conducted beneath Rainier Mesa was published in the mid-1970's 9. At most 2 to $3 \%$ of the refractory radionuclides -including the actinides - are lost from "good 'puddle' glass samples (collected at the bottom of the test cavity) in which other refractories are equally well-retained" ${ }^{9}$. General experience from the U.S. nuclear testing program based on radiochemical diagnostic data collected from a variety of test matrices suggest that $95 \pm 5 \%$ of the test-specific inventory of refractory radionuclides are contained in the melt fraction. 
It is important to resolve whether the plutonium detected at the downgradient well cluster is derived from the $95 \%$ fraction resident in the melt glass or the $5 \%$ sited outside the glass. If plutonium outside the glass is indeed implicated as the source, other tests conducted in fractured rock aquifers may also be at similar risk for the transport of plutonium at or near ambient groundwater velocities.

\section{EXPERIMENTAL}

The present study targets samples taken from a post-test drilling into a single nuclear test cavity and chimney at the Nevada Test Site. This test was conducted in Tertiary volcanic tuffs and was detonated below the static water level. Solid debris and melt glass samples were also recovered below the device depth of burial. The name of the test is not revealed to avoid disclosing test-specific phenomenology and radiochemical signatures which are classified.

\section{Solid Samples}

Samples were collected from a post-shot drilling operation that targeted both the melt glass at the base of the cavity as well as overlying collapse debris. Six samples were analyzed from the single test. Sampling was conducted using a Hunt side-wall tool which forces samples into a shoe under the weight of the drill-bit. Five samples were taken sequentially over a slant depth interval of $69 \mathrm{~m}$ from one borehole (hole 1) and one 
additional sample of melt glass was taken from a secondary boring (hole 2) drilled into the same test cavity.

Samples taken from the melt puddle consisted of vitreous, dense samples of darkcolored melt glass, while the samples taken from the collapse region were brecciated samples of light colored ash typical of the in-fall environment. It is noteworthy that both glass and ash samples are interspersed throughout the approximately 70 meter sampling interval within the bottom half of the test cavity. The chaotic juxtaposition of glass and lithic materials is a result of the collapse of the standing cavity and creation of the rubble chimney. During this process, glass may get "splashed" or otherwise displaced higher in the cavity region.

Analytical Methods

Analysis of actinides in the solid samples involves the separation of uranium and plutonium from the samples and measurement of isotope ratios and concentrations using isotope dilution with a non-isobarically interfering enriched isotope spike ${ }^{233} \mathrm{U}$ and ${ }^{244} \mathrm{Pu}$ ). Magnetic sector, multi-collector inductively coupled mass spectrometry was used for the high-sensitivity, high-precision measurements of actinide concentrations and isotope ratios of uranium and plutonium. Two-sigma errors on the isotope ratio measurements for ${ }^{235} \mathrm{U} /{ }^{238} \mathrm{U}$ averaged 0.000016 and two-sigma errors on the isotope ratio measurements for ${ }^{240} \mathrm{Pu} /{ }^{239} \mathrm{Pu}$ averaged 0.002 . Both errors are considerably lower than the variations in the measured isotope ratios. 


\section{RESULTS}

Uranium and plutonium were detected in all of the samples. Uranium occurs in natural concentrations of several parts-per-million (microgram/gram) in the silicic tuffs and rhyolites of the Nevada Test Site and its presence is these samples is expected. The presence of plutonium is significant because it provides unambiguous evidence that weapons-derived actinides were dispersed throughout the cavity and collapse chimney.

\section{Uranium Data}

The uranium data are presented in Table 1 . The concentrations vary only slightly between 3 and 4 micrograms per gram (parts-per-million, ppm) and are consistent with natural uranium abundances in the tuff that comprise the host media for this test. Assuming 700 metric tons of rock is melted per kiloton of nuclear yield ${ }^{7-8}$, more than 7000 metric tons of rock is melted in a 10 kiloton yield underground explosion. The amount of natural uranium from the native rock incorporated in the melt glass will range between $2.1 \mathrm{E}+4$ grams (assuming a 3 ppm initial concentration in the native rock) and $2.8 \mathrm{E}+4$ grams (assuming $4 \mathrm{ppm}$ initial concentration in the native rock).

The presence of ${ }^{236} \mathrm{U}$, as well as anomalies in the ${ }^{235} \mathrm{U} /{ }^{238} \mathrm{U}$ isotope ratio and ${ }^{234} \mathrm{U} /{ }^{238} \mathrm{U}$ activity ratio are indicative of the presence of uranium derived from unburned actinide fuels or device parts. ${ }^{236} \mathrm{U}$ is enriched in the production of uranium fuels for use in nuclear weapons. The ${ }^{235} \mathrm{U} /{ }^{238} \mathrm{U}$ isotope ratio in nature is 0.0072527 . Corresponding ${ }^{234} \mathrm{U} /{ }^{238} \mathrm{U}$ activity ratios are 1.0 for samples in secular equilibrium. Two of the six 
samples show large enrichments in ${ }^{235} \mathrm{U}$ isotopic composition, ${ }^{236} \mathrm{U}$ concentration, and

${ }^{234} \mathrm{U}$ activity that unequivocally demonstrates the incorporation of a bomb fraction. Not unexpectedly these samples correspond to the dark melt-glass samples that preferentially partition the actinides. Early in nuclear testing program uranium was discovered to be slightly volatile in the high temperature underground environment accompanying a nuclear test. Using the ${ }^{235} \mathrm{U} /{ }^{238} \mathrm{U}$ isotope ratio and ${ }^{236} \mathrm{U}$ concentration as signatures, we can infer that weapons-derived uranium was transported away from the device during detonation and became incorporated in the damage zones or region of chimney collapse. However the large amount of natural uranium in the rock overwhelms any uranium isotopic signature from the device. For this reason, absolute uranium concentrations do not vary between samples.

\section{Plutonium Data}

Plutonium concentration data is presented in Table 2. The variation in ${ }^{239} \mathrm{Pu} /{ }^{240} \mathrm{Pu}$ isotope ratios is approximately $15 \%$ between samples of the collapse breccia and the melt glass; individual isotope ratios have been omitted in keeping with classification guidance. Plutonium is unequivocally diagnostic of the test device due to the absence of any naturally occurring isotopes of this radionuclide. The analytical results show the highest concentrations of plutonium are associated with the melt glass fraction (Sample \#3 and Sample \#6). Glass Sample \#4 contains relatively low concentrations of plutonium and is reddish in color with a flow-banded texture that suggests it may represent a volcanic glass. 
The data indicate the presence of plutonium in samples taken outside of the meltglass horizon. Plutonium concentrations in the ash samples range from 3.0E-2 to $6.9 \mathrm{E} 0$ nanograms/gram (parts-per-billion, ppb). It is unknown how the plutonium is sited within these crystalline matrices.

\section{DISCUSSION}

At the NTS, there have only been a few studies of the distribution of radionuclides in melt-glass ${ }^{9-11}$ and only one documented case of actinides being transported by prompt injection outside of the immediate cavity and chimney system ${ }^{12}$.

We have plotted the distribution of actinides with depth in the lowermost cavity and collapse zone in Figure 1. Variations in the ${ }^{235} \mathrm{U}{ }^{238} \mathrm{U}$ ratio clearly mimic those for plutonium concentrations. Notably there is not a regular enrichment in actinide concentrations with depth but rather a sharp spike in enrichment in residual actinides at mid-level within the cavity-collapse environment. This is the result of melt glass that has become incorporated higher in the cavity environment likely due to the chaotic in-fall of displaced rock accompanying the collapse of the cavity. Glass was displaced and "splashed" upwards as cooler blocks fell into the melt puddle and the melt rapidly cooled in the void space between the chimney rubble.

Isotope ratios and concentrations measured in these samples provide new insight into the underground phenomenology, distribution, and transport of plutonium underground. Figure 2 plots the isotope ratio of plutonium verses concentration in nanograms per gram. Labels for the measured ${ }^{239} \mathrm{Pu} /{ }^{240} \mathrm{Pu}$ ratios are omitted pursuant to 
classification guidance. Samples fall along a hyperbolic trend that is indicative of two component mixing. The melt glass end-member has enriched plutonium concentrations but a lower ${ }^{239} \mathrm{Pu} /{ }^{240} \mathrm{Pu}$ isotope ratios than the end-member samples of ash taken higher in the collapse zone. As a check on the mixing relations, a companion plot of plutonium isotope ratios relative to the inverse of the plutonium concentration is linear as expected of a true two-component mixture.

There is only one initial (i.e., fixed) plutonium isotope ratio associated with the device. The fact that the plutonium data plot on a two-component mixing line demonstrates that the plutonium isotopes were fractionated during transport immediately following the detonation. Fractionation of plutonium is likely the result of the volatilization of uranium and the production of ${ }^{239} \mathrm{Pu}$ by the reaction ${ }^{238} \mathrm{U}(\mathrm{n}, \square) \cdot{ }^{240} \mathrm{Pu}$ is not affected. Accordingly, fractionated samples will exhibit a corresponding increase in the associated ${ }^{239} \mathrm{Pu} /{ }^{240} \mathrm{Pu}$ isotope ratio. Radiochemical diagnostics associated with the nuclear testing program have long incorporated a volatility correction for uranium fractionated in the high temperature underground environment accompanying a nuclear test. The $10 \%$ to $20 \%$ percent volatilization of uranium is well documented and is consistent with thermodynamic studies of uranium oxides at high temperatures and steam pressures ${ }^{13}$. If the source of ${ }^{239} \mathrm{Pu}$ is volatilized and activated uranium, ${ }^{236} \mathrm{U}$ should behave similarly since this uranium isotope is only enriched during the production of nuclear weapons fuels. Figure 3 plots ${ }^{239} \mathrm{Pu}$ concentration in nanograms per gram verses ${ }^{236} \mathrm{U}$ concentration in nanograms per gram. The ${ }^{239} \mathrm{Pu}$ concentrations are again omitted to avoid compromise of classified information. The two isotopes show a linear correlation. 


\section{CONCLUSIONS}

The results of this work clearly indicate the heterogeneous radiochemical environment that exists in the aftermath of an underground nuclear explosion. The textural and radiochemical profile indicates that the melt glass that initially accumulates on the floor of the standing cavity is subsequently displaced as blocks are chaotically dropped into the melt during subsequent cavity collapse.

Furthermore, this data unequivocally shows that plutonium may be dispersed throughout the cavity environment at the time immediately following the detonation. This plutonium is associated with fine grained, brecciated, volcanic ash samples that occur within the collapsed region. Mixing diagrams demonstrate that plutonium isotope ratios are fractionated during transport immediately following the explosion, and suggest that the plutonium sequestered in the melt has mixed with the ash samples. The plutonium is fractionated by volatilization of uranium in the high temperatures and steam pressures accompanying the underground explosion and the corresponding production of

${ }^{239} \mathrm{Pu}$ by the reaction ${ }^{238} \mathrm{U}(\mathrm{n}, \square)$. The fractionated plutonium in the ash is present in extremely low concentrations that are three to four orders of magnitude below those encountered in the melt glass and is available for release to groundwater through surface reactions with the ash. We conclude that for the test under consideration plutonium that was deposited outside of the melt glass is most likely to be transferred to the groundwater regime. This source may complement release of a larger reservoir of plutonium available through longer-term and slower dissolution of the melt-glass. 


\section{ACKNOWLEDGEMENT}

Diane Loewen performed the solid core dissolutions and uranium and plutonium chemical extractions for this investigation as part of a nuclear science internship program sponsored by the Glenn T. Seaborg Institute at the Lawrence Livermore National

Laboratory. This work was performed under the auspices of the U.S. Department of Energy by the University of California, Lawrence Livermore National Laboratory under Contract No. W-7405-Eng-48.

\section{REFERENCES}

1. I.Y. BORG, R. STONE, H.B. LEVY, L.D. RAMSPOTT, Lawrence Livermore National Laboratory, UCRL-52078 (1976).

2. R.W. BUDDEMEIER, R.C. FINKEL, K.V. MARSH, M.R. RUGGIERI, J.H. REGO, R.J. SILVA, Radiochim. Acta, 52/53, (1991) 275.

3. A.B. KERSTING, D.W. EFURD, D.L. FINNEGAN, D.J. ROKOP, D.K. SMITH, J.L. THOMPSON, Nature, 397, (1999) 56. R.G. BEDFORD, D.D. JACKSON, Lawrence Radiation Laboratory Report, UCRL-12314 (1965).

4. A.F.B. TOMPSON, C.J. BRUTON, G.A. PAWLOSKI, D.K. SMITH, W.L. BOURCIER, D.E. SHUMAKER, A.B. KERSTING, S.F. CARLE, R.M. MAXWELL, Environ. Geology, 42 (2002) 235.

5. G.J. NIMZ, J.L. THOMPSON, U.S. Department of Energy, Nevada Field Office, DOE/NV-346, (1992).

6. J.L. THOMPSON, J.S. GILMORE, Radiochim. Acta, 52/53 (1991) 229.

7. C.W. OLSEN, Lawrence Livermore National Laboratory, UCRL-70379 (1967).

8. G.A. PAWLOSKI, Lawrence Livermore National Laboratory, UCRL-ID-136003 (1999).

9. I.Y. BORG, Nuc. Technology, 26 (1975) 88. 
10. D.K. SMITH, Radiochim. Acta, 69, (1995) 157.

11. G.F. EATON, D.K. SMITH, J. Radioanalytical and Nuc. Chem., 248, (2001) 543.

12. T.P.ROSE, D.K. SMITH, D.L. PHINNEY, Radiochim. Acta, 88, (2000) 465.

13. R.G. BEDFORD, D.D. JACKSON. Lawrence Radiation Laboratory Report, UCRL12314 (1965). 
Table 1. Uranium concentration (in $\square \mathrm{g} / \mathrm{g}$ ), ${ }^{236} \mathrm{U}$ concentration in $\mathrm{ng} / \mathrm{g},{ }^{235} \mathrm{U} /{ }^{238} \mathrm{U}$ isotope ratio, and ${ }^{234} \mathrm{U} /{ }^{238} \mathrm{U}$ activity ratio for glass and ash samples with increasing depth in the collapse chimney and cavity.

\begin{tabular}{|lccccc|}
\hline Sample & $\begin{array}{c}\text { Relative } \\
\text { Slant Depth }\end{array}$ & $\begin{array}{c}\text { Uranium } \\
\text { Concentration } \\
\text { in } \square \mathrm{g} / \mathrm{g}\end{array}$ & $\begin{array}{c}{ }^{236} \mathrm{U} \\
\text { Concentration } \\
\text { in } \mathrm{ng} / \mathrm{g}\end{array}$ & $\begin{array}{c}{ }^{235} \mathrm{U} /{ }^{238} \mathrm{U} \text { Isotope } \\
\text { Ratio }\end{array}$ & $\begin{array}{c}{ }^{234} \mathrm{U} /{ }^{238} \mathrm{U} \\
\text { Activity Ratio }\end{array}$ \\
\hline 1 & shallow & 4.11 & 0.0047 & 0.00727 & 1.022 \\
2 & & 3.12 & 0.0224 & 0.00735 & 1.122 \\
3 & & 4.32 & 16.930 & 0.10110 & 41.152 \\
4 & & 3.72 & 0.0136 & 0.00733 & 1.020 \\
5 & & 3.22 & 0.9847 & 0.01397 & 3.8383 \\
6 & deep & 3.98 & 5.3110 & 0.03730 & 13.908 \\
\hline
\end{tabular}

Table 2. Sample type (glass or ash) and plutonium concentration in $\mathrm{ng} / \mathrm{g}$ with increasing depth in the collapse chimney and cavity.

\begin{tabular}{|lccc|}
\hline Sample & $\begin{array}{c}\text { Relative } \\
\text { Slant Depth }\end{array}$ & Sample Type & $\begin{array}{c}\text { Plutonium } \\
\text { Concentration } \\
\text { in ng/g }\end{array}$ \\
\hline 1 & shallow & ash & $3.02 \mathrm{E}-2$ \\
2 & & ash & $1.03 \mathrm{E}-1$ \\
3 & & glass & $1.58 \mathrm{E}+2$ \\
4 & & glass & $1.23 \mathrm{E}-1$ \\
5 & & ash & $6.86 \mathrm{E} 0$ \\
6 & deep & glass & $4.81 \mathrm{E}+1$ \\
\hline
\end{tabular}


$235 \mathrm{U} / 238 \mathrm{U}$ isotope ratio

plutonium concentration in $\mathbf{n g} / \mathbf{g}$

uranium concentration in micrograms/g

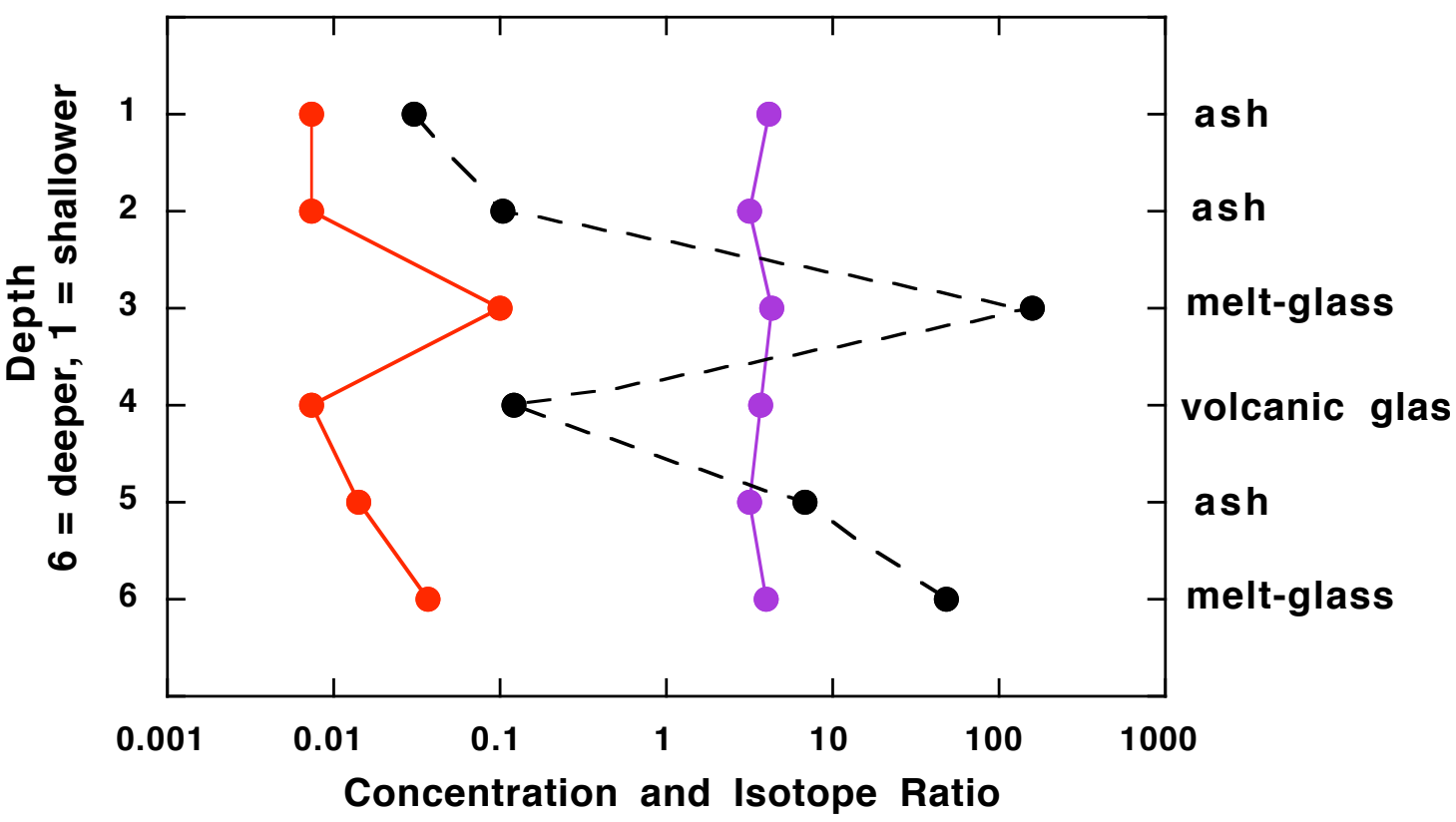

Figure 1. Plot of the distribution of ${ }^{235} \mathrm{U} /{ }^{238} \mathrm{U}$ isotopes (red), uranium concentrations in micrograms per gram (purple), and plutonium concentrations in nanograms per gram (black) in cores taken from the base of the melt puddle $($ depth $=6)$ upwards in the collapse chimney $($ depth $=1)$. Sample type with depth indicated on right axis. 


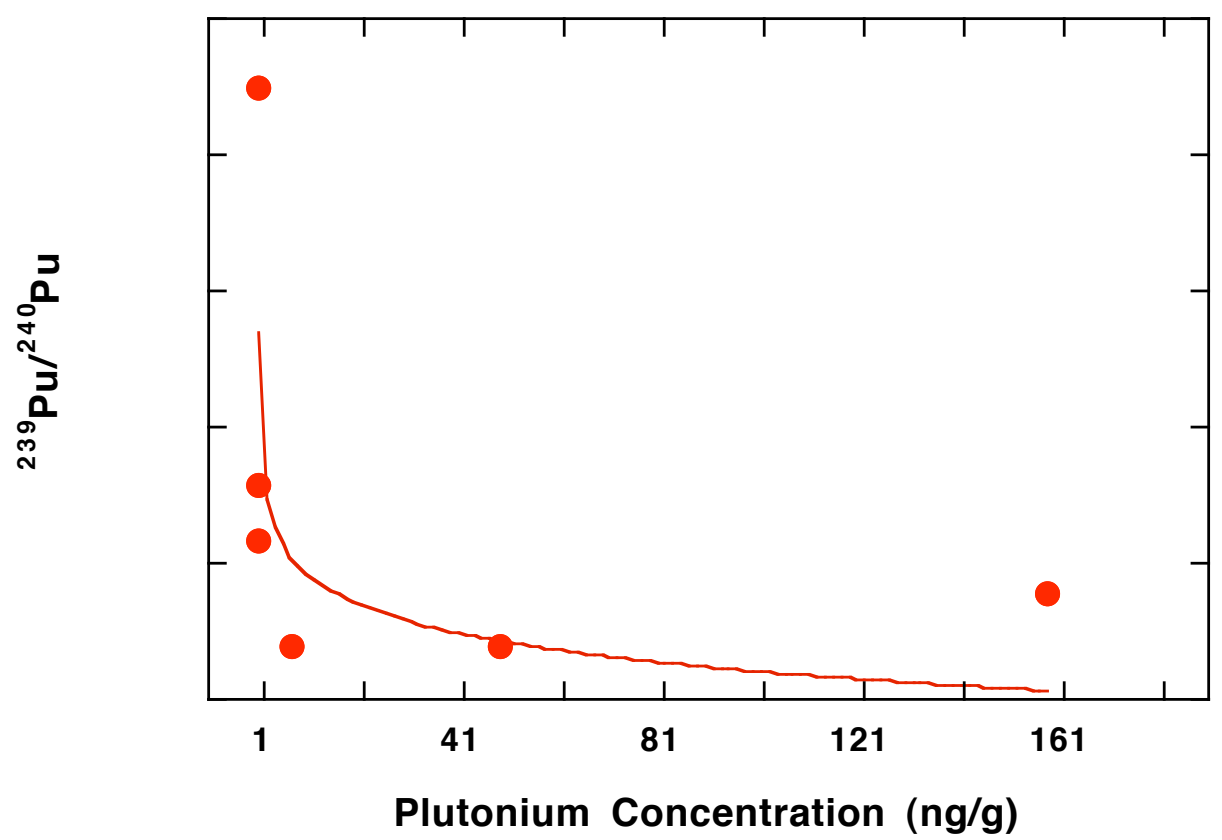

Figure 2. Plot of ${ }^{239} \mathrm{Pu} /{ }^{240} \mathrm{Pu}$ isotope ratio (the ordinate label is omitted) and plutonium concentration in nanograms per gram. A hyperbolic mixing line joins plutonium enriched melt glass samples with lower ${ }^{239} \mathrm{Pu} /{ }^{240} \mathrm{Pu}$ isotope ratios to plutonium depleted samples with enriched ${ }^{239} \mathrm{Pu} /{ }^{240} \mathrm{Pu}$ ratios. 


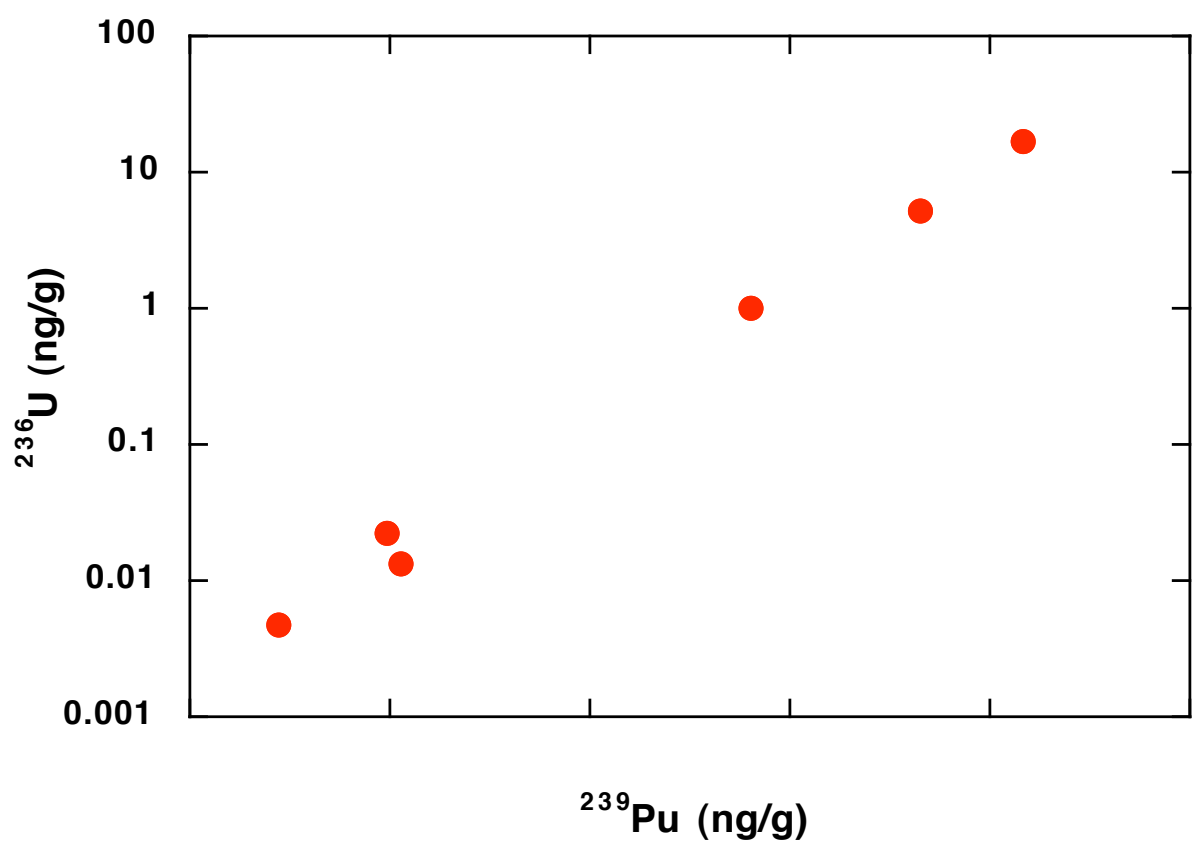

Figure 3. Plot of ${ }^{236} \mathrm{U}$ in nanograms per gram verses ${ }^{239} \mathrm{Pu}$ in nanograms per gram (abscissa label omitted). Melt glass samples are enriched in ${ }^{236} \mathrm{U}$ and ${ }^{239} \mathrm{Pu}$ relative to the collapse breccia. The linear correlation of the ${ }^{236} \mathrm{U}$ and ${ }^{239} \mathrm{Pu}$ suggests the plutonium was formed from neutron capture of volatilized uranium. 